\title{
Growth and yield responses of commercial sugarcane cultivars to mulching in the coastal rainfed region of South Africa
}

\author{
BNG Nxumalo $^{1,2}$, S Ramburan $^{1}$ and JM Steyn ${ }^{2}$ \\ ${ }^{1}$ South African Sugarcane Research Institute, Private Bag X02, Mount Edgecombe, 4300 \\ ${ }^{2}$ Department of Plant Production and Soil Science, University of Pretoria, Private Bag X20, Hatfield, \\ 0028, South Africa. Received
}

(Nathi.Nxumalo@sugar.org.za)

\begin{abstract}
The perceived negative cultivar responses to mulching has limited the adoption of this practice in the South African sugarcane industry. This study was aimed at evaluating cane yield and quality responses and population dynamics of popular cultivars to mulching in the rainfed region of South Africa. A four replicate field trial was established using a strip-plot design. Cane and tons estimated recoverable crystal yields (TERC), and yield components were determined in three summer ratoons and one winter ratoon. In-season soil water and temperature were monitored. Mulching significantly improved cane and TERC of all cultivars across ratoons. The highest improvements in cane and TERC were $85 \%$ (N45) and 92\% (N39) respectively. The improvements were attributed to the higher soil water content under the mulch blanket. Stalk heights, mass and population (winter ratoon) were improved at harvest for most cultivars across ratoons with mulching. Mulching reduced emergence and tillering presumably due to lower soil temperatures under the mulch blanket. The highest mulch-yielding cultivars were N47 and N42, and they increased yield by 15 and $13 \mathrm{th} \mathrm{ha}^{-1}$ respectively. Mulching was beneficial for sugarcane production, regardless of the cultivar and
\end{abstract}


ratooning season and can be recommended for all current cultivars in the coastal rainfed region.

Key words: cane yield, cultivars, mulching, ratoon, sugarcane

\section{Introduction}

Sugarcane (Saccharum spp.) in South Africa is grown under a wide range of agro-climatic conditions. Approximately $70 \%$ of total sugarcane production occurs under rainfed conditions, with average rainfall ranging from 800 to $1200 \mathrm{~mm}$ per annum (Van Antwerpen et al. 2006). In the rainfed regions (mainly located along the coastal areas of Kwa-Zulu Natal province), sugarcane is typically harvested between April (early season, autumn) and December (late season, summer) at 12 to 15 months of age. It is estimated that approximately $90 \%$ of the area under cane along the coastal region is burnt at harvest to facilitate manual harvesting of the crop.

Mulching, which is defined as the physical removal and spreading of leaf material from the previous crop over the next ratoon crop (Oliver and Singels 2006), has received worldwide attention as a sustainable management practice in sugarcane production. The practice has been shown to have substantial positive impacts on sugarcane yield, especially under low rainfall conditions (De Beer et al. 1995: Digonzelli et al. 2011). Despite this, grower uptake of mulching as a routine practice has been poor. Reasons for the lack of uptake of mulching include increased labour costs, reduction in harvest efficiency of cane cutters, increased transport and maintenance required by machinery, and increased accident risks for manual sugarcane cutters. 
On the other hand, there are numerous agronomic and economic advantages associated with mulching. Various studies have linked yield increases in sugarcane to the ability of the mulch blanket to retain soil water and reduce evapotranspiration (Murombo et al. 1997; Ball-Coelho et al. 1993; Van Antwerpen et al. 2006). Woods (1991) reported a 10\% yield improvement with mulching as compared to burning in Australia. Under South African rainfed conditions, Van Antwerpen et al. (2001) compared burnt and mulched treatments and reported cane yield increases of $6 \mathrm{tha}^{-1}$ and $9 \mathrm{tha}^{-1}$ per annum in favour of mulching. In Argentina, Digonzelli et al. (2011) evaluated sugarcane production for mulched and burnt cane in two harvest cycles (summer and winter harvest). In their experiment they found that the cane yield improvements due to mulching were 12 and $55 \%$ in the summer and winter ratoons, respectively.

In contrast, other studies have reported a decline in cane yield in the presence of a mulch blanket (Torres and Villegas 1995; Kingston 2002; Kingston et al. 2005). In these studies the decline in cane yield seems to be most severe under cool and wet conditions. A mulch blanket modifies the local growing environment by altering soil temperature, radiation interception and weed competition (Wynne and van Antwerpen 2004). These factors in turn can affect the growth and population dynamics of the crop during the growing season. For example, lower soil temperatures under the mulch blanket have been reported to slow down emergence and initial growth of sugarcane (Morandini et al. 2005; Digonzelli et al. 2009), leading to slower canopy development and thus lower radiation interception. This suggests that the effects of mulching are not always beneficial, and factors such as ratoon age (influences stalk population), time of harvest, and cultivar, are important considerations. Furthermore, factors such as soil type (Van Antwerpen et al. 2002; Sandhu et al. 2013) and seasonal rainfall (Van Antwerpen et al. 2006) have been shown to play an integral role in the overall yield responses to mulching. 
A factor that has received less attention in sugarcane mulch research is cultivar responses. Sugarcane cultivars differ considerably in their agronomic characteristics and their reaction to management practices. Differences in cultivar physiology and phenology will determine how they respond to the agronomic practice of mulching (Olivier and Singels 2015). The majority of studies on mulching have involved a limited number of cultivars (Thompson 1966; Morandini et al. 2005; Nunez and Spaans 2007; Olivier et al. 2009; Viator et al. 2009; Digonzelli et al. 2011; Viator and Wang 2011). The South African sugarcane industry has a wide range of cultivars that are bred for specific production regions. Currently, the coastal region of KwaZulu-Natal has about 32 cultivars that are permitted for planting. Of these commercial cultivars, only six to eight currently contribute significantly to sugar production in the region (Ramburan 2013). Recently, there have been industry reports of reduced growth vigour, establishment, and yields of certain cultivars through mulch blankets in the coastal rainfed region. However, no quantitative information exists on the reaction of these popular commercial cultivars to mulching. An understanding of the growth and yield reactions of cultivars to mulching will allow for cultivar-specific recommendations and/or adjustments of current agronomic practices to maximise yields and improve adoption. Additionally, efforts to promote green cane harvesting and subsequent biomass utilisation for electricity cogeneration are being hampered by negative reports of cultivar growth and yield responses to mulching. Linked to this issue, is the associated lack of data on actual biomass yields produced by different cultivars.

In addition to being cultivar specific, many previous studies on mulching have been conducted over a limited number of crops (Torres and Villegas 1995; Olivier et al. 2009), and at specific harvest times only (Morandini et al. 2005; Nunez and Spaans 2007; Romero et al. 2009). In order to fully understand and implement the practice of mulching, a comprehensive evaluation of the influences of cultivar, year, ratoon, and season (early vs. late) is therefore 
necessary. Therefore, the objectives of this study were to: (a) quantify effects of mulch vs. burnt conditions on yield components of common commercial cultivars in the coastal rainfed region of South Africa, (b) compare these cultivars under mulch vs. burnt conditions with respect to their growth, establishment, and population dynamics, (c) monitor the influence of mulching on factors such as soil water and temperature in order to explain yield responses, and (d) quantify the amount of mulch material produced by the different commercial cultivars.

\section{MATERIALS AND METHODS}

A field experiment was established in October 2008 on a SASRI research farm located at Empangeni in the north coast of Kwa-Zulu Natal (28 $\left.43^{\prime} 0^{\prime \prime} \mathrm{S} 31^{\circ} 53^{\prime} 0^{\prime \prime} \mathrm{E}\right)$. The trial consisted of eight sugarcane cultivars which are commonly grown in the region (NCo376, $\mathrm{N} 27, \mathrm{~N} 35, \mathrm{~N} 39, \mathrm{~N} 41, \mathrm{~N} 42, \mathrm{~N} 45$ and N47). The trial was laid out as $2 \times 8 \times 4$ factorial strip plot design with two harvesting treatments (burnt vs. mulch) as the main plots (strips), eight cultivars as the sub plots, with four ratoon crops harvested. The trial was replicated four times. Trial plots consisted of five rows each that were $7 \mathrm{~m}$ long and spaced $1.2 \mathrm{~m}$ apart. Following trial establishment in 2008 , the plant crops were grown to maturity (12 months) and harvested in 2009. At harvest, mulch blankets were then put down for the mulch treatments, and growing season measurements were then initiated in the first ratoon crop. The same process was then followed for subsequent ratoons. The trial was harvested annually late in the season (October) for three "summer" crops (R1, R2, and R3). The fourth ratoon crop was grown for a period of eight months and then "cut back" in June. The subsequent fifth ratoon was then harvested the following June at an age of 12 months. This was done to bring the trial into a "winter" cycle and evaluate the responses to mulching when growing through winter. The fifth ratoon (R5) is therefore referred to as the "winter" crop. 
Weather data (rainfall $(\mathrm{mm})$ ) was collected during each growing season (ratoon) from an automatic weather station (AWS) situated at the experimental site. The long term mean (LTM) monthly rainfall was also calculated for each site to characterise the growing seasons in terms of rainfall. The LTM represents the mean monthly rainfall data from 2003 up until the harvest dates. Growth measurements were taken at two week intervals from $2 \times 2 \mathrm{~m}$ sections which were randomly assigned to net rows (experimental lines) prior to emergence. Tiller counts (stalk population) were determined within the $2 \mathrm{~m}$ sections, whereas stalk height was measured from 10 randomly selected plants per plot at each measurement event. The final stalk population was determined by counting all of the millable cane from two of the three net rows at harvest. Stalk population was subsequently expressed as the number of stalks per hectare.

At each harvest, stalk samples were taken by cutting 12 stalks from the net rows for determination of the estimated recoverable crystal percentage (ERC \%). The ERC\% is a quality parameter derived from an equation that accounts for the amount of sucrose, nonsucrose, and fibre in cane deliveries. Cane yield in tons cane/ha (TCANE) was measured by hand-cutting and weighing the net plots with a mechanical grab apparatus fitted with a load cell. Tons of ERC/ha (TERC), was calculated as a product of TCANE and ERC. The TERC is the commercial parameter for which growers are remunerated in the industry.

From each of the 12 stalks used for sucrose sampling, the components of mulch which included green leaves and dead brown leaves were separated into brown paper bags. These components were dried at $75{ }^{\circ} \mathrm{C}$ for approximately 72 hours. The samples were then weighed to calculate the total mulch yield (tons/ha) for each cultivar on a dry mass basis. 
Soil water content was measured using soil moisture sensors (10HS, Decagon Devices, Pullman, USA). The sensors were installed at 20-25 cm depths in selected burnt and mulched treatments (six replicates) of the same cultivar and readings were taken at two week intervals.

Hobo data loggers (Onset Computer Corporation, Bourne, USA) were used to monitor soil temperature. The devices were set to log temperatures every 15 minutes and were installed at a depth of $15-20 \mathrm{~cm}$ in selected mulched and burnt plots of the same cultivars.

All parameters measured at each harvest were subjected to a combined analysis of variance (ANOVA) to establish cultivar, mulch, and ratoon and their interactions. Comparison of means was performed using Duncan's LSD test at 5\% significant difference and statistical analyses were done using GenStat Statistical Package version 14.

\section{RESULTS}

\section{Seasonal characteristics}

Rainfall patterns and distributions differed across all four cropping seasons. The first few summer months after ratooning in the first ratoon (R1) had rainfall similar to the long term mean (LTM), however, rainfall dropped below the LTM later in the season in winter (Figure 1a). Generally, the second ratoon (R2) had above LTM rainfall over most of the cropping period and was considered as a good season. In contrast, rainfall in the third ratoon (R3) was generally below the LMT for most months between December and August, suggesting that this was a harsher season compared with the previous two. The fifth ratoon (R5) started at the end of June (Figure 1b) and rainfall was generally below the LTM from June to September. The month of October and March received the highest rainfall, thereafter the rainfall dropped below LTM towards the end of the growing season. 

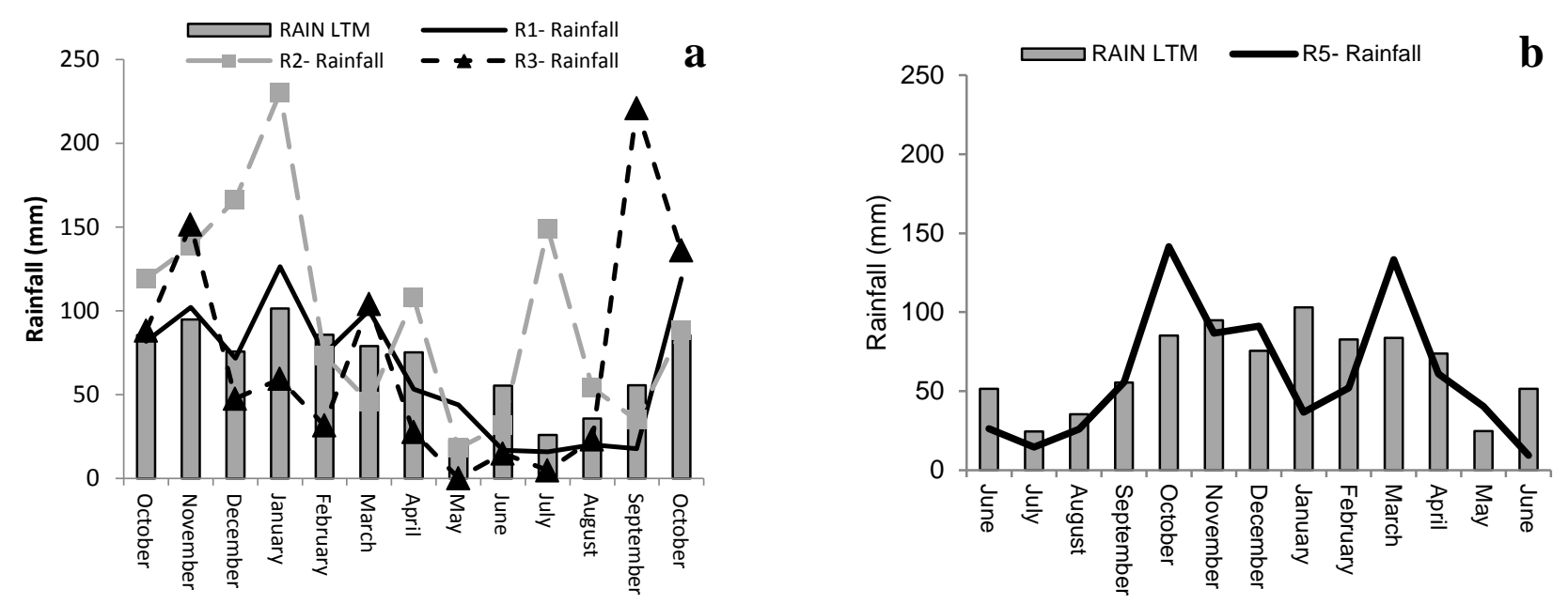

Figure 1 Monthly mean and long term mean (LTM) rainfall taken from an automatic weather station in the first (R1), second (R2) and third (R3) summer ratoon (a) and fifth winter ratoon (R5) crop (b) at Empangeni (The x-axis are synchronised with the harvesting months).

\section{Yield and yield components}

The combined analysis of variance showed that the ratoon (R), mulch (M) and cultivar (C) main effects were significant for all yield components, in general (Table 1). The mulch effect accounted for more variation in cane yield and stalk mass compared to the ratoon effect (as suggested by the size of the mean square values). However, for yield components such as ERC\%, TERC, stalk population and stalk height, $\mathrm{R}$ had a greater effect on the total variation as compared to M. Moreover, for all yield components, except for ERC\%, the C source of variation had the least effect on the total variation. The $\mathrm{R} \times \mathrm{M}$ and $\mathrm{R} \times \mathrm{C}$ interactions were also significant for most of the yield components, with exception of stalk mass. Furthermore, the $\mathrm{R} \times \mathrm{M}$ interaction had a greater effect on the total variation for all yield components as compared to all the other interaction effects. Generally, the C x M interaction and three way $\mathrm{R} \times \mathrm{M} \times \mathrm{C}$ interaction was not significant with respect to cane yield, TERC, stalk population, stalk heights and stalk mass. 
Table 1 Mean square values from a combined analysis of variance (ANOVA) for all yield components across four ratoons for eight cultivars under burnt and mulched treatments.

\begin{tabular}{cccccccc}
\hline $\begin{array}{c}\text { Source of } \\
\text { variation }\end{array}$ & df & $\begin{array}{c}\text { Cane yield } \\
(\mathbf{t} / \mathbf{h a})\end{array}$ & ERC\% & TERC & $\begin{array}{c}\text { Stalk population } \\
\left(\mathbf{1 0 0 0 / \mathbf { h } ^ { - 1 }}\right)\end{array}$ & $\begin{array}{c}\text { Stalk } \\
\text { heights } \\
(\mathbf{c m})\end{array}$ & $\begin{array}{c}\text { Stalk mass } \\
(\mathbf{g})\end{array}$ \\
Ratoon (R) & 3 & $11919.8^{* *}$ & $256.9^{* *}$ & $416.5^{* *}$ & $6323000^{* *}$ & $71657.7^{* *}$ & $438109.0^{* *}$ \\
Mulch (M) & 1 & $12597.6^{*}$ & $12.9^{*}$ & $230.1^{* *}$ & $3042000^{*}$ & $14747.6^{* *}$ & $718031.0^{* *}$ \\
Cultivar (C) & 7 & $354.9^{*}$ & $16.5^{*}$ & $12.7^{* *}$ & $1575000^{* *}$ & $2619.0^{* *}$ & $71290.0^{* *}$ \\
R x M & 3 & $282.3^{* *}$ & $2.2^{*}$ & $2.4^{*}$ & $1758000^{* *}$ & $1246.7^{* *}$ & $16296.0^{* * *}$ \\
R x C & 21 & $87.3^{* *}$ & $1.8^{* *}$ & $1.6^{* *}$ & $435700^{* *}$ & $337.8^{* *}$ & $4056.0^{\text {ns }}$ \\
C x M & 7 & $45.3^{\text {ns }}$ & $1.6^{*}$ & $1.5^{\text {ns }}$ & $106800^{\text {ns }}$ & $66.1^{\text {ns }}$ & $4236.0^{\text {ns }}$ \\
R x M x C & 21 & $23.1^{\text {ns }}$ & $0.5^{\text {ns }}$ & $0.6^{\text {ns }}$ & $159400^{\text {ns }}$ & $70.9^{\text {ns }}$ & $3709.0^{\text {ns }}$ \\
\hline$*$ and ** indicates significant (P<0.05) and highly significant $(\mathrm{P}<0.001)$ respectively and ns indicates non significance of the source of \\
variation
\end{tabular}

In general, cane yields were significantly $(\mathrm{p}<0.05)$ improved by the mulch treatment across all four ratoon crops for most of the cultivars (Figure 2). However, in the second ratoon crop, where high rainfall $(230 \mathrm{~mm})$ was received before canopy closure (Figure 1a), the improvement due to mulching was marginal (in comparison to other crops) and not statistically significant for some cultivars (Figure 2b). The cane yield improvements due to mulching were different across all four ratoon crops. The highest yield improvements were found for cultivars $\mathrm{N} 47$ (53\%), N39 (27\%), NCo376 (58\%) and N45 (85\%) in the first, second, third and fifth ratoon, respectively (Figure 2).

The responses of TERC were similar to the responses of cane yield. The mulch treatment significantly $(\mathrm{P}<0.001)$ improved TERC for most cultivars across all four ratoons (Figure 3). The highest TERC improvements due to mulching were observed for N47, with 72 and $74 \%$ in the first and third ratoon, respectively. In the second and fifth ratoon, cultivar N39 showed the highest improvements of 42 and $92 \%$, respectively. The effects of mulching on ERC\% 

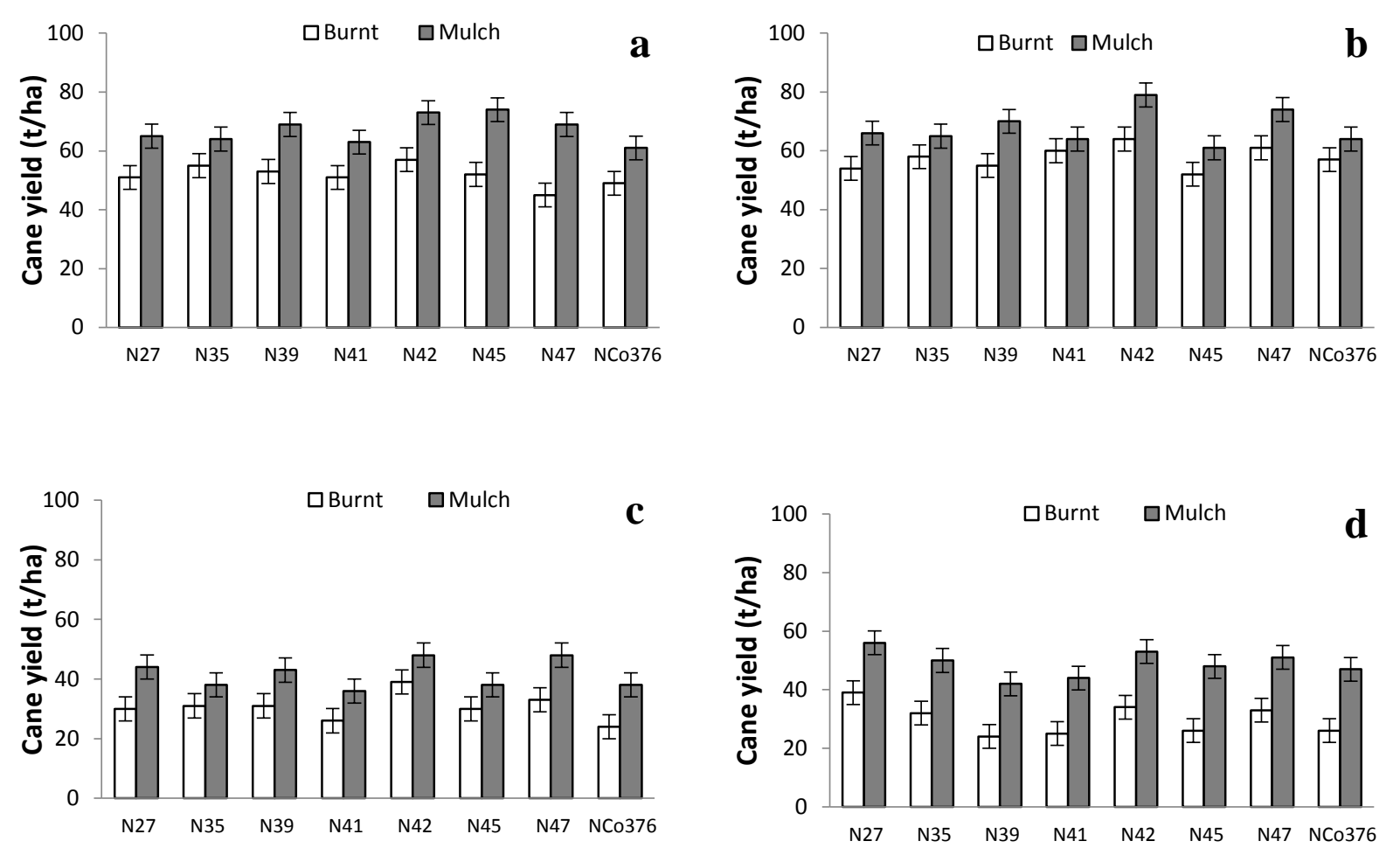

Figure 2 Cane yields for eight different sugarcane cultivars under burnt and mulch treatments in the first (a), second (b) third (c) and fifth (d) ratoon crops at Empangeni. Vertical bars represent least significant differences $(\mathbf{p}<0.05)$.

varied across cultivars and crops, ranging from marginal improvements to marginal reductions due to mulching (not shown).

In all three summer ratoons (R1, R2 and R3) stalk population, stalk height and stalk mass were affected similarly by mulching, and as a result the means across the three crops for each of these variables are presented here. The responses to mulching in the fifth (winter) ratoon were different, and are therefore presented separately (Table 2). There were no significant differences in final stalk population due to mulching for all cultivars in the summer ratoons (Table 2). However, in the winter crop (fifth ratoon), the mulch treatment significantly 

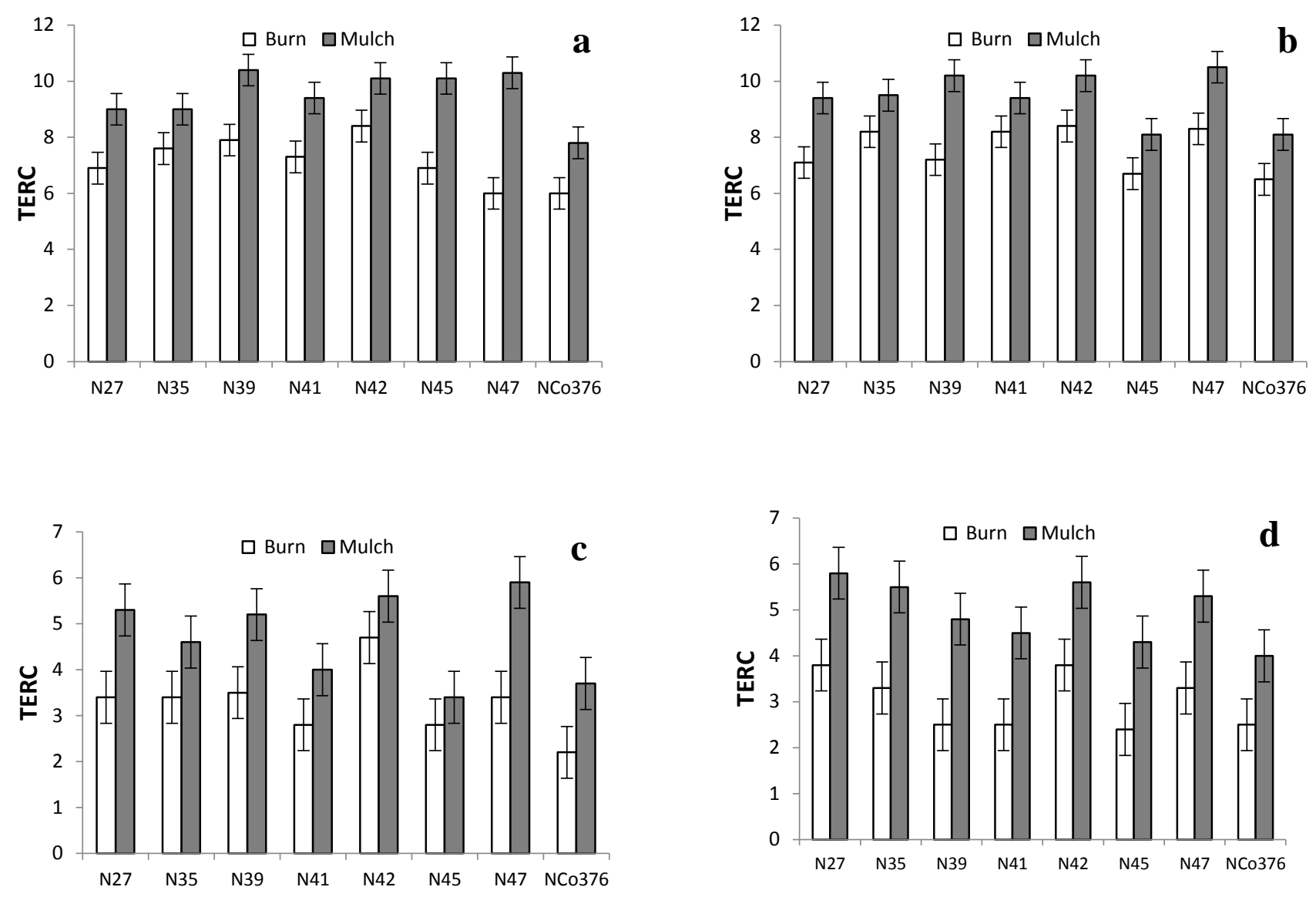

Figure 3 Tons ERC (TERC) for eight different sugarcane cultivars under burn and mulch treatments in the first (a), second (b) third (c) and fifth (d) ratoon crops at Empangeni. Vertical bars represent least significant differences $(\mathbf{p}<\mathbf{0 . 0 5})$.

improved stalk populations for most cultivars, with the exception of cultivars N42 and N27 (Table 2).

Stalk heights, on the other hand, were significantly improved by mulching for most cultivars (except NCo376), when averaged over all three summer ratoons (Table 2). In the winter crop, all cultivars showed significant improvements in stalk height with mulching. The individual stalk mass was generally improved by mulching for all cultivars in both the summer and winter ratoons. Greater improvements in stalk mass and stalk heights due to mulching were 
Table 2 Mean of three summer crops (R1, R2 and R3) and one winter crop (R5) for stalk population, stalk height, and stalk mass at Empangeni under mulched and burnt conditions (means followed by the same letter were not significantly different between burnt and mulched conditions).

\begin{tabular}{|c|c|c|c|c|c|c|c|}
\hline \multirow{2}{*}{ Cultivars } & \multirow{2}{*}{ Treatment } & \multicolumn{3}{|c|}{ MEAN OF SUMMER CROPS (R1, R2 and R3) } & \multicolumn{3}{|c|}{ WINTER CROP (R5) } \\
\hline & & Stalk population/ha & Stalk heights (cm) & Stalk mass (g) & Stalk population/ha & Stalk heights $(\mathrm{cm})$ & Stalk mass $(g)$ \\
\hline $\mathbf{N 2 7}$ & $\begin{array}{l}\text { Burnt } \\
\text { Mulch }\end{array}$ & $\begin{array}{l}116091^{\mathrm{a}} \\
117773^{\mathrm{a}}\end{array}$ & $\begin{array}{l}159^{\mathrm{a}} \\
171^{\mathrm{b}}\end{array}$ & $\begin{array}{l}415^{\mathrm{a}} \\
528^{\mathrm{b}}\end{array}$ & $\begin{array}{l}102083^{\mathrm{a}} \\
115923^{\mathrm{a}}\end{array}$ & $\begin{array}{l}104^{\mathrm{a}} \\
122^{\mathrm{b}}\end{array}$ & $\begin{array}{l}351^{\mathrm{a}} \\
501^{\mathrm{b}}\end{array}$ \\
\hline N35 & $\begin{array}{l}\text { Burnt } \\
\text { Mulch }\end{array}$ & $\begin{array}{l}127495^{\mathrm{a}} \\
128457^{\mathrm{a}}\end{array}$ & $\begin{array}{l}150^{\mathrm{a}} \\
159^{\mathrm{b}}\end{array}$ & $\begin{array}{l}401^{\mathrm{a}} \\
481^{\mathrm{b}}\end{array}$ & $\begin{array}{l}111310^{\mathrm{a}} \\
133036^{\mathrm{b}}\end{array}$ & $\begin{array}{l}82^{\mathrm{a}} \\
111^{\mathrm{b}}\end{array}$ & $\begin{array}{l}248^{\mathrm{a}} \\
413^{\mathrm{b}}\end{array}$ \\
\hline N39 & $\begin{array}{l}\text { Burnt } \\
\text { Mulch }\end{array}$ & $\begin{array}{l}134623^{\mathrm{a}} \\
144360^{\mathrm{a}}\end{array}$ & $\begin{array}{l}147^{\mathrm{a}} \\
162^{\mathrm{b}}\end{array}$ & $\begin{array}{l}381^{\mathrm{a}} \\
428^{\mathrm{b}}\end{array}$ & $\begin{array}{l}93304^{\mathrm{a}} \\
118006^{\mathrm{b}}\end{array}$ & $\begin{array}{l}67^{\mathrm{a}} \\
96^{\mathrm{b}}\end{array}$ & $\begin{array}{l}209^{\mathrm{a}} \\
377^{\mathrm{b}}\end{array}$ \\
\hline N41 & $\begin{array}{l}\text { Burnt } \\
\text { Mulch }\end{array}$ & $\begin{array}{l}124608^{\mathrm{a}} \\
131870^{\mathrm{a}}\end{array}$ & $\begin{array}{l}156^{\mathrm{a}} \\
169^{\mathrm{b}}\end{array}$ & $\begin{array}{l}411^{\mathrm{a}} \\
497^{\mathrm{b}}\end{array}$ & $\begin{array}{l}100149^{a} \\
120089^{b}\end{array}$ & $\begin{array}{l}77^{\mathrm{a}} \\
104^{\mathrm{b}}\end{array}$ & $\begin{array}{l}240^{\mathrm{a}} \\
391^{\mathrm{b}}\end{array}$ \\
\hline $\mathbf{N} 42$ & $\begin{array}{l}\text { Burnt } \\
\text { Mulch }\end{array}$ & $\begin{array}{l}122019^{\mathrm{a}} \\
120769^{\mathrm{a}}\end{array}$ & $\begin{array}{l}156^{\mathrm{a}} \\
168^{\mathrm{b}}\end{array}$ & $\begin{array}{l}464^{\mathrm{a}} \\
593^{\mathrm{b}}\end{array}$ & $\begin{array}{l}104464^{\mathrm{a}} \\
116220^{\mathrm{a}}\end{array}$ & $\begin{array}{l}87^{\mathrm{a}} \\
120^{\mathrm{b}}\end{array}$ & $\begin{array}{l}321^{\mathrm{a}} \\
523^{\mathrm{b}}\end{array}$ \\
\hline $\mathbf{N 4 5}$ & $\begin{array}{l}\text { Burnt } \\
\text { Mulch }\end{array}$ & $\begin{array}{l}143388^{\mathrm{a}} \\
141057^{\mathrm{a}}\end{array}$ & $\begin{array}{l}153^{\mathrm{a}} \\
163^{\mathrm{b}}\end{array}$ & $\begin{array}{l}340^{\mathrm{a}} \\
423^{\mathrm{b}}\end{array}$ & $\begin{array}{l}104911^{\mathrm{a}} \\
129762^{\mathrm{b}}\end{array}$ & $\begin{array}{l}81^{\mathrm{a}} \\
112^{\mathrm{b}}\end{array}$ & $\begin{array}{l}233^{\mathrm{a}} \\
361^{\mathrm{b}}\end{array}$ \\
\hline N47 & $\begin{array}{l}\text { Burnt } \\
\text { Mulch }\end{array}$ & $\begin{array}{l}131791^{\mathrm{a}} \\
135352^{\mathrm{a}}\end{array}$ & $\begin{array}{l}156^{\mathrm{a}} \\
171^{\mathrm{b}}\end{array}$ & $\begin{array}{l}366^{\mathrm{a}} \\
491^{\mathrm{b}}\end{array}$ & $\begin{array}{l}112500^{\mathrm{a}} \\
134077^{\mathrm{b}}\end{array}$ & $\begin{array}{l}81^{\mathrm{a}} \\
106^{\mathrm{b}}\end{array}$ & $\begin{array}{l}259^{\mathrm{a}} \\
397^{\mathrm{b}}\end{array}$ \\
\hline NCo376 & $\begin{array}{l}\text { Burnt } \\
\text { Mulch }\end{array}$ & $\begin{array}{l}135208^{a} \\
135253^{a}\end{array}$ & $\begin{array}{l}132^{\mathrm{a}} \\
139^{\mathrm{a}}\end{array}$ & $\begin{array}{l}354^{\mathrm{a}} \\
425^{\mathrm{b}}\end{array}$ & $\begin{array}{l}101637^{a} \\
124851^{b}\end{array}$ & $\begin{array}{l}74^{\mathrm{a}} \\
92^{\mathrm{b}}\end{array}$ & $\begin{array}{l}255^{\mathrm{a}} \\
381^{\mathrm{b}}\end{array}$ \\
\hline
\end{tabular}


observed in the winter crop, compared to the summer crops. The weakest response to mulching in the second ratoon with respect to stalk population, stalk height and stalk mass (Table 2) can be related to higher rainfall received during the peak growing season (January) (Figure 1a). In contrast, the best responses to mulching in the fifth ratoon for the same yield components (Table 2) was related to low rainfall during peak growing season in January (Figure 1b). These results give an indication of the effect of the mulch layer in both high rainfall (sufficient water available (Figure 1a (second ratoon)) and water limiting (Figure 1b) seasons.

\section{Effects of mulching on canopy development}

In all the ratoon crops the growth patterns were similar for most cultivars when stalk population and stalk heights for each cultivar $\mathrm{x}$ mulch treatment was plotted as a function of days after ratooning. The mean of all cultivars in both treatments are therefore shown (Figure 4). The burn treatment generally had significantly higher stalk population at the early emergence stage compared to the mulch treatments and this was consistent across all ratoons for all cultivars. In the first ratoon, the differences lasted up until peak stalk population, where after differences between the treatments were no longer significant for the rest of the season (Figure 4a). In the second ratoon, the significantly higher stalk population in the burn treatment was observed only at the early emergence stage. These differences were no longer present from peak stalk population onwards (Figure 4b). Similarly, in the third ratoon, the burnt treatment had significantly higher stalk population at the start of the growing season, there after the differences faded away (Figure 4c). The winter crop took longer to reach peak stalk population when compared to the three summer crops for both the mulch and the burn treatment (Figure 4d). In this ratoon, the higher stalk population in the burn treatment 

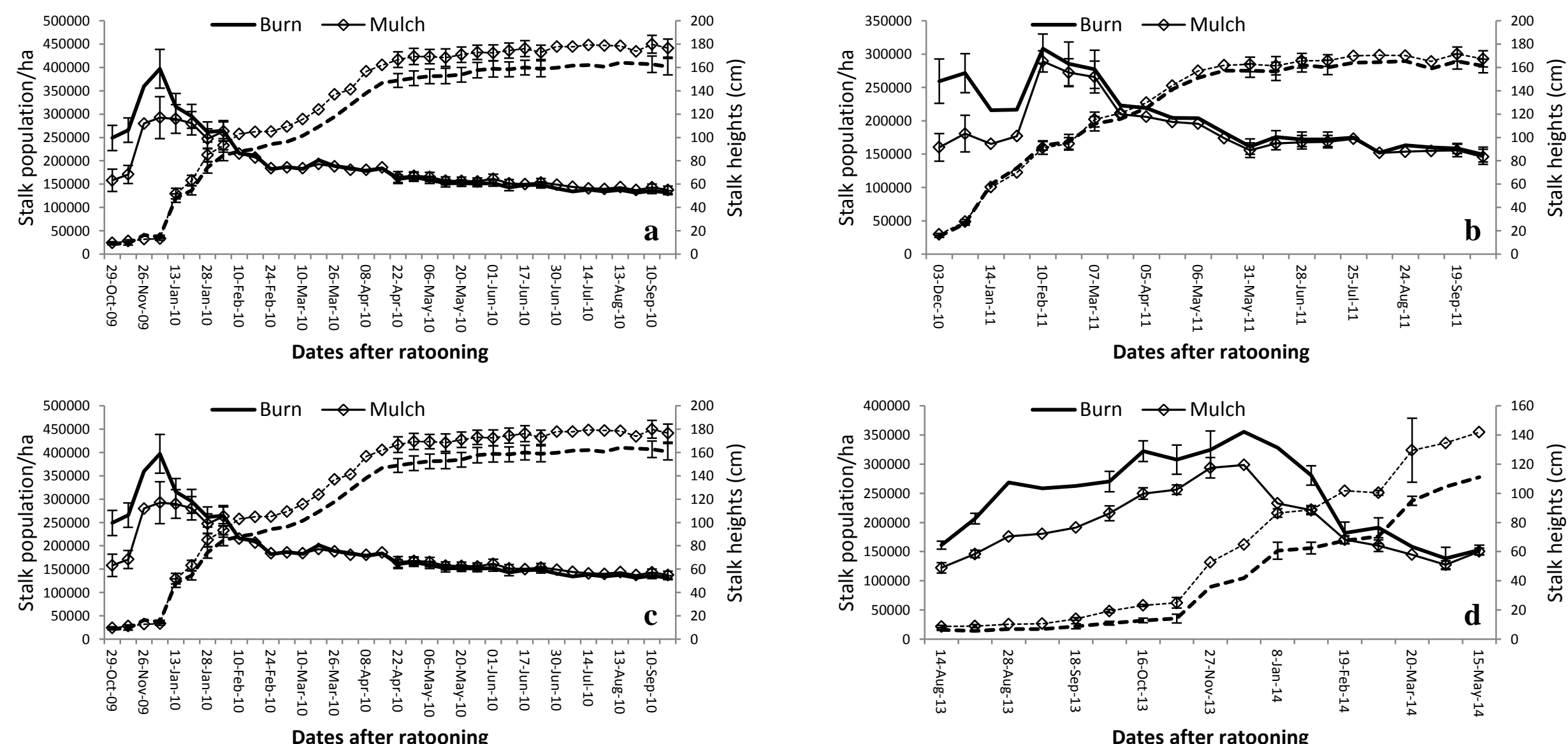

Figure 4 Mean sugarcane cultivar stalk population (primary axis - solid line) and stalk heights (secondary axis - square dots) as a function of days after ratooning as affected by burn and mulch treatments in the (a) first, (b) second, (c) third and (d) fifth (winter) ratoon. The LSDs (p<0.05) is indicated by error bars at selected points only. 
persisted even after peak stalk population, however, from late January 2014 (approximately 209 days after ratooning) the differences became non-significant.

No differences in stalk height were observed between the burn and mulch treatment at the beginning of the rapid stalk elongation phase in both the first and the third ratoon (Figure $4 \mathrm{a}$ and $4 \mathrm{c})$. Thereafter, the stalks in the mulch treatment were consistently taller compared to the burn treatment throughout the growing season in both ratoons. In contrast, no significant differences in stalk height between the burn and the mulch treatment was observed in the second ratoon throughout the growing season (Figure 4b). In the fifth ratoon, the mulch treatment had a much more rapid stalk elongation compared with the burnt treatment. The rapid stalk elongation was observed from emergence but became more significant from early October 2013 (about 97 days after ratooning), and persisted until harvest (Figure 4d).

\section{Effects of mulching on soil water content}

Volumetric soil water content was consistently higher in the mulch treatments throughout the growing season for all ratoons (Figure 5). The first ratoon (Figure 5a) generally had the smallest percentage water content difference between the treatments as compared to the other ratoons. In the first and fifth ratoons, the differences in soil water content were higher early in the growing season, and these differences became smaller as the season progressed. In the second and third ratoons, the differences between burn and mulch treatments remained consistent throughout the growing season (Figure $5 \mathrm{~b}$ and $5 \mathrm{c}$ ). 

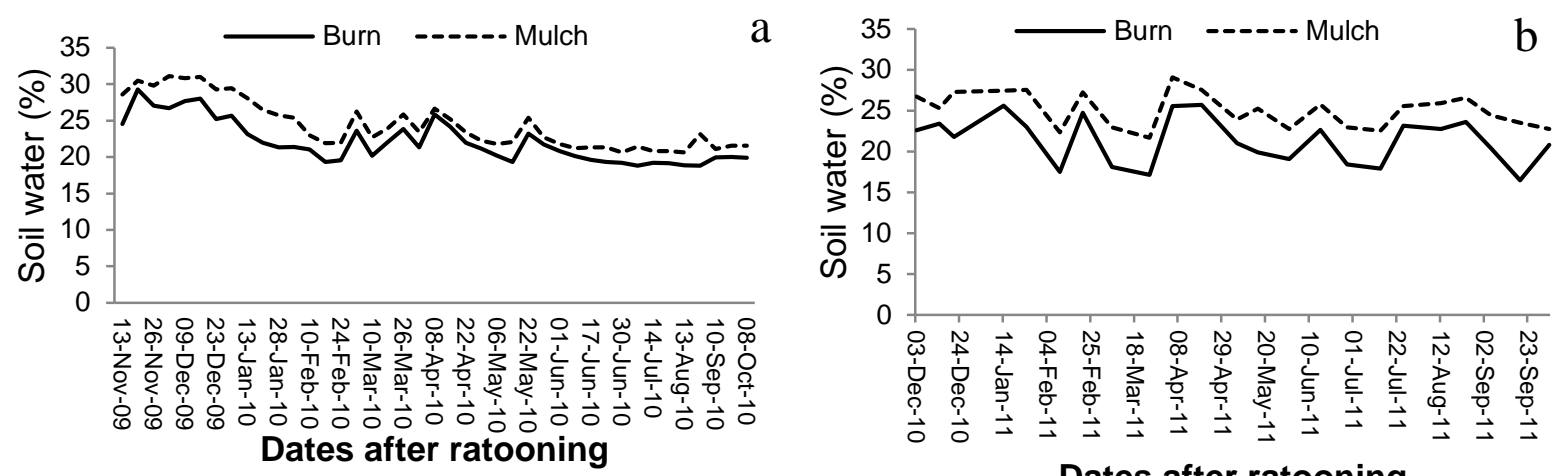

Dates after ratooning
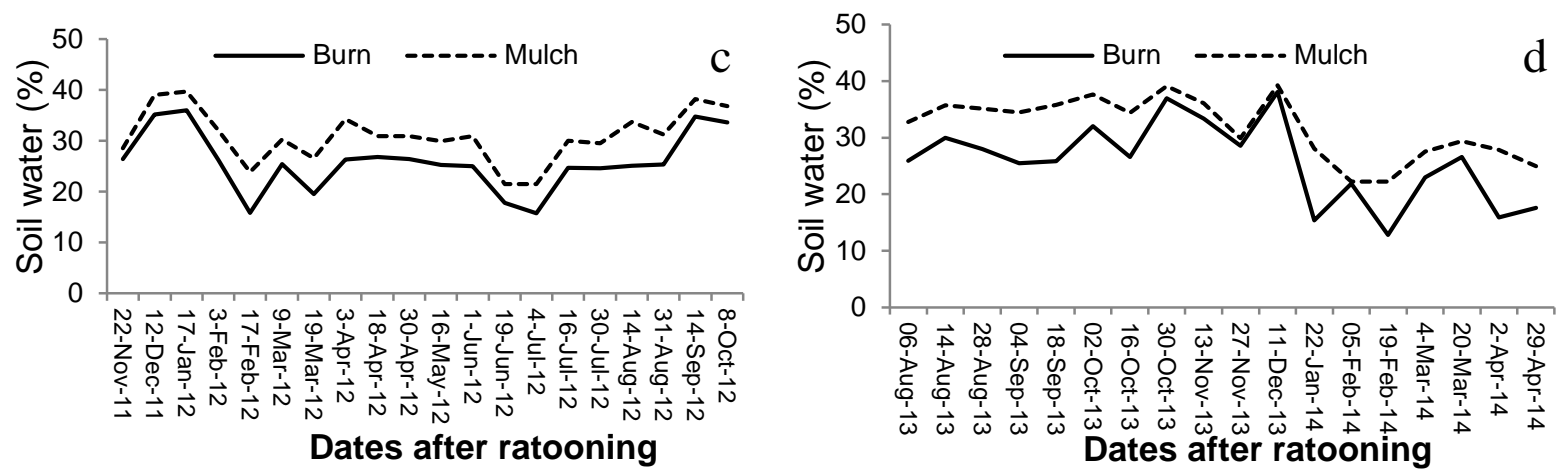

Figure 5 Changes in volumetric soil water content (in percentage) across the growing season as affected by burn and mulch treatment for (a) first ratoon crop (b) second ratoon crop (c) third ratoon crop and (d) fifth ratoon crop (data not shown up to harvest).

\section{Effects of mulching on soil temperature}

Soil temperature differences between burnt and mulched treatments were shown from the start up until the end of the growing season during the fifth ratoon crop (Figure 6). Diurnal temperature variations were remarkably reduced by mulching throughout the season. Early in the season soil temperatures under mulch were kept at an average of $18{ }^{\circ} \mathrm{C}$ but temperatures increased later in the season. Daily maximum soil temperatures in the burn treatment were always greater than the mulch throughout the growing season. However, minimum soil temperatures early in the season were sometimes lower than the mulch treatment. Soil temperature differences between burn and mulch were greater early and mid-season at partial 
canopy closure. The temperatures under mulch were kept at a constant average of about $25{ }^{\circ} \mathrm{C}$ during the mid-season. The differences between the two treatments faded away later in the season as the canopy closed. The burn treatment at this point had reduced diurnal soil temperature fluctuations. At the end of the season soil temperatures under the burn treatments were reduced more than that of the mulch treatment.

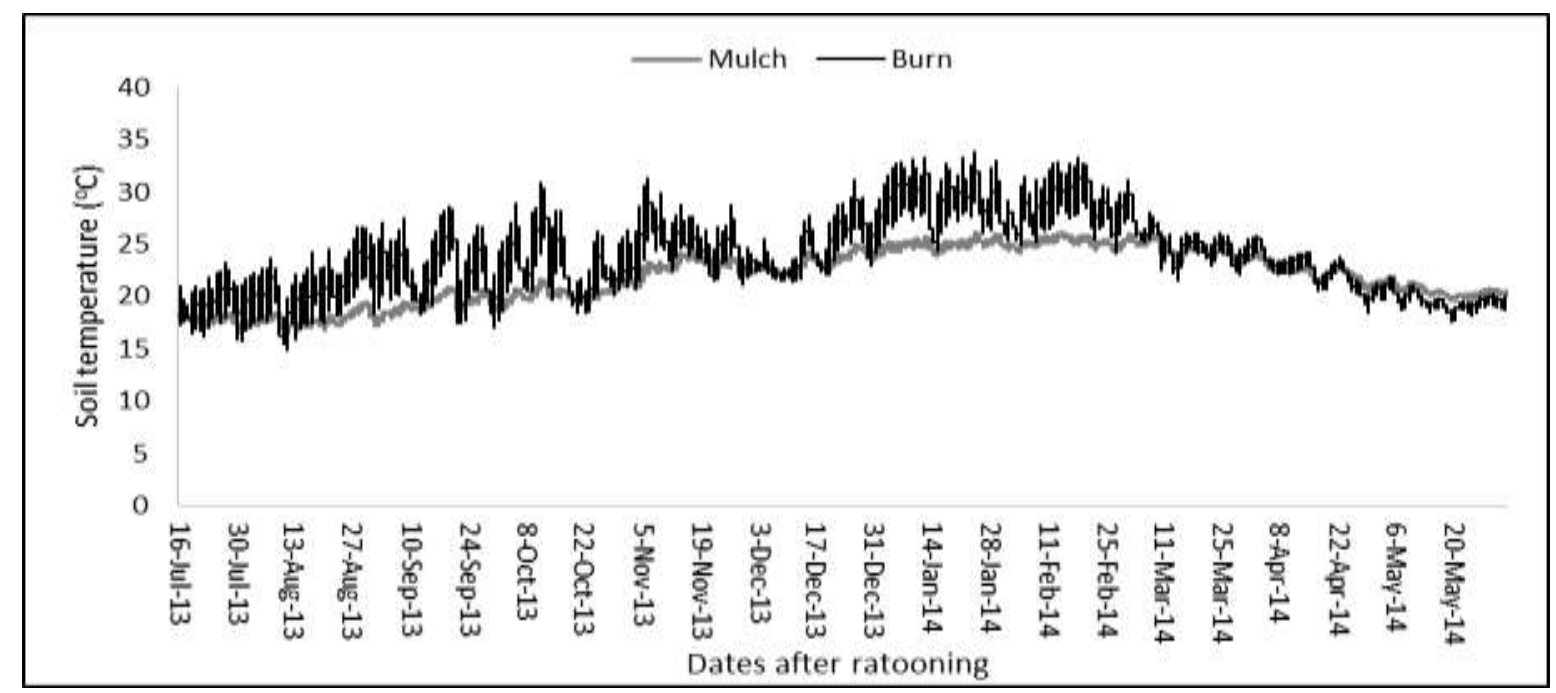

Figure 6 Soil temperature regimes under mulch and burn treatment in a fifth sugarcane ratoon crop from the start to end of the growing season. Temperatures were logged every 15 minutes at $15-20 \mathrm{~cm}$ depths in adjacent burnt and mulched plots of the same cultivar.

\section{Mulch production by cultivars}

The estimated mulch production by different cultivars was different in each production season (Figure 7). The second ratoon (R2) had the highest mulch yields in general. Generally, the estimated mulch production decreased with each successive ratoon. Cultivar N47 was the highest mulch yielding cultivar in all ratoons, ranging from as high as $20 \mathrm{t} \mathrm{ha}^{-1}$ in the second (sufficient water, no stress) ratoon to10 $\mathrm{tha}^{-1}$ in the fifth ratoon (water stressed). N45 was the lowest mulch yielding cultivar $\left(13 \mathrm{t} \mathrm{ha}^{-1}\right)$ in a high production year (R2), while NCo376 produced the lowest quantities of mulch in both the third and the fifth ratoon with $7.6 \mathrm{tha}^{-1}$ in 
both ratoons. The mulch yield/cane yield ratios per cultivar ranged from $30 \%$ for cultivar N47 to $23 \%$ for both cultivars N41 and N45 in the second ratoon. In the third ratoon the ratios ranged from $33 \%$ for $\mathrm{N} 47$ to $24 \%$ for cultivar N35. In the fifth ratoon the ratios ranged from 24\% for both cultivars N49 and N39 to 20\% for cultivar N47 (Data not presented). However, there were no strong correlations $\left(\mathrm{R}^{2}=0.486\right)$ in the second ratoon. In the third and fifth ratoon there were positive and moderate correlations $\left(R^{2}=0.78\right.$ and $R^{2}=0.65$ respectively) between mulch yield and cane yield.

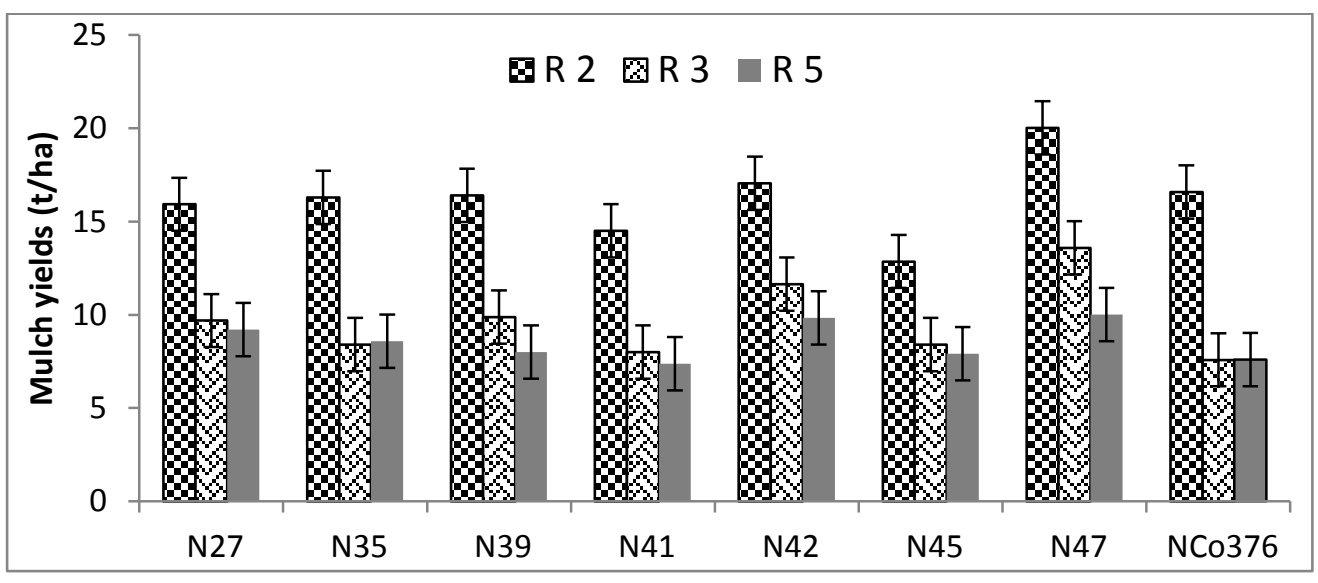

Figure 7 Sugarcane mulch yield estimates of eight cultivars at Empangeni over a period of three ratoon crops. Vertical bars represent least significant differences $(p<0.05)$.

\section{Discussion}

Mulching generally improved cane yields, regardless of the ratooning season (summer crop or winter crop) (Figure 2). The dominant effect of mulching on cane yield were also illustrated by the magnitude of the mean square values relative to the effects of the other sources of variation (Table 1). The cane yield improvements due to mulching were, however, variable from one crop to the next and between cultivars within the same cropping season. The differences in improvement were likely due to the differences in amount and seasonal distribution of rainfall from one crop to the next (Figure 1). From the rainfall data, it was 
clear that the second ratoon crop had above LTM rainfall for most of the critical sugarcane growing period and therefore did not suffer much water stress as compared to the other crops. This resulted in the second ratoon crop having the least improvements due to mulching of $18 \%$ as compared to 30,36 and $64 \%$ in the first, third and fifth ratoon respectively. These results are in agreement with those reported by Van Antwerpen et al (2001), where they found that yield response to a mulch treatment decreased with an increase in rainfall. De Beer et al (1995) also reported that yield gains under mulched conditions can mostly be observed in exceptionally dry or low rainfall areas. Furthermore, Van Antwerpen et al (2001) reported $12 \%\left(9 \mathrm{t} \mathrm{h}^{-1}\right)$ yield improvements by mulching in the coastal regions in dry periods. Studies conducted with mulching have mostly associated cane yield improvements with its ability to retain soil water better as compared to bare conditions. In the current study, the mulch treatment maintained higher soil water content throughout the growing season for all four ratoon crops (Figure 5). The soil water content differences between burn and mulch treatments were the driving force for cane yield improvements, especially in ratoons (crops) with below LTM rainfall during critical times of the growing season. Thompson (1965) also reported that the potential conservation of water by mulching would be more beneficial under conditions of inadequate rainfall in South Africa.

Cane yield is expressed as sugarcane mass per land unit. It is therefore a function of final stalk population (millable stalks/ha) and individual stalk mass (Orgeron 2000). From the results presented in Table 2 for stalk population it was clear that stalk population did not play a role in improving cane yield in the summer ratoons, as no significant differences were observed between treatments. A study by Digonzelli et al. (2011) also reported that there were no significant differences in stalk population between the burn and the mulch treatment of a 2006/2007 crop harvested in summer. In contrast, the significantly higher stalk population at harvest for the mulch treatment at the fifth ratoon contributed to better 
improvements in cane yield as compared to the three summer crops. However, it is not final stalk population alone that determines the final yield improvements for a specific cultivar. Mean stalk mass is another important variable that drives the final cane yield. The significant improvement in stalk mass in the summer crop contributed highly to the improvement in cane yield (Table 2). Mean stalk mass is further determined by components such as stalk height and stalk diameter. In this experiment stalk diameter was not measured. Mulch treatments significantly $(\mathrm{P}<0.001)$ affected stalk heights (Table1). The higher water content in the mulch plots (Figure 5) may have indeed contributed to continual stalk elongation, thereby leading to taller stalks at harvest, especially in the fifth ratoon (winter crop). In contrast, stalk height for most cultivars was not significantly affected by mulching in the second ratoon crop (results not presented), the reason being that the second ratoon crop received above LTM rainfall for most part of the growing season (Figure 1b), thereby eliminating the advantage of having a mulch blanket.

Estimated recoverable crystal yield (TERC) is a product of cane yield and ERC and is a key economic factor to consider when choosing a cultivar. It was apparent that cultivar N39 and N47 have higher economical returns when mulched and the least economic returns can be expected from N35, N41 and N42 (Figure 3). The higher TERC in the mulched treatment for both cultivar N47 and N39 were a result of improvement in both cane yield and ERC\% (results not presented) of these cultivars. In the first ratoon crop N39 and N42 had significantly improved cane yields (Figure 2a) and both had reduced ERC\% but had significantly improved TERC due to mulching (Figure 2a). Accordingly, in the fifth ratoon crop, cultivar NCo376 had significantly improved cane yields, and although ERC\% was significantly reduced due to mulching, the TERC was significantly improved. However, in the third ratoon crop, the cane yield improvement for N45 was not significant, but ERC\% were numerically higher in the mulch treatment compared to the burn, but this did not lead to 
significantly improved TERC values. All of this proves that even though both cane yield and ERC\% contribute to final TERC, a more vigorous crop, hence higher cane yield, contributes to a greater extent to improvements in TERC. Ahmed and Khaled (2008) also reported that cane yield is the most important component of sugar yield (TERC).

In order to fully understand the effects that the mulch treatments (burn and mulch) had on sugarcane cultivars, it was important to study their growth and development during the growing season. In this study the significant delay in emergence due to mulching that was observed for all cultivars in all four ratoons (Figure 4) was possibly due to lower soil temperatures under the mulch blanket. In the winter ratoon lower soil temperatures early in the season under mulch were recorded (Figure 6). The results of this study are in line with those reported by Torres and Villegas (1995) and Morandini et al. (2005), where they also found a reduction in stalk population where cane was mulched. In their study reduction was also attributed to lower soil temperature prevalent under the mulch blanket. Beater and Maud (1962) also reported that mulching had a retarding effect on initial crop growth and tillering. In contrast Digonzelli et al. (2011) reported no significant differences in emergence between the burn and mulch treatment in a summer ratoon, they attributed this to temperatures that were always above $20{ }^{\circ} \mathrm{C}$ throughout the growing season.

Generally, after peak stalk population and canopy closure, differences between burn and mulch treatment fade away (Chapman et al. 2001 and Olivier and Singles 2012). This was in agreement with the findings in this study in all the ratoons (Figure 4). The similarities in stalk population between the treatments were also manifested on the final stalk population for the summer ratoons (Table 2). In the first, third, and fifth ratoon crop (Figure $4 \mathrm{a}, \mathrm{c}$ and $\mathrm{d}$ respectively) the stalks in the mulched treatment elongated quicker than the burn because of the consistently higher soil water in the mulch treatment (Figure 5). Olivier and Singles (2012) also reported similar results; they also reported that stalk elongation was highly 
sensitive to water stress. On the other hand, the second ratoon did not experience much water stress, hence no significant differences in stalk elongation were observed (Figure 4b).

\section{Conclusions}

Mulching generally improved cane yield of all cultivars across all four seasons in the coastal rainfed region. The magnitude of the improvements differed from one cultivar to the next and with ratoons, with drier seasons having a higher cane yield improvement due to mulching. The improvements in cane yield were primarily attributed to the higher soil water content prevalent under the mulch blanket.

Although ERC\% response to mulching was variable for cultivars and across seasons, TERC for all cultivars was significantly improved by mulching, regardless of the ratoon. Cultivar N47 had the highest improvement in TERC for the drier summer ratoons and cultivar N39 had the highest improvements in a wet summer ratoon and in a winter ratoon. Improvements in TERC were mostly due to improved cane yields rather than ERC\%.

All cultivars showed delayed emergence and tillering due to mulching, both in winter and summer ratoons. This delay in emergence and establishment was attributed to lower soil temperatures under the mulch blanket. In general, this retarding effect of the mulch blanket disappeared later during the season and as a result no significant differences in stalk population, especially in the summer ratoons, were observed towards the end of the growing season for most cultivars.

The amount of mulch produced was dependent on the cane yields produced in that season and varied between cultivars. High cane yielding ratoons had higher mulch yields and vice versa. Moreover, the positive and moderate correlation coefficient between mulch and cane yield in 
the third and fifth ratoon indicate that the higher the production level (cane yield), the higher the mulch yields to be expected in the field.

Additionally, the data generated in this study regarding population dynamics, yield responses of cultivars, and seasonal responses in burnt vs. mulched conditions can contribute to improve modelling of this recommended practice under rainfed conditions. Furthermore, information generated on mulch yields of different cultivars will assist in future decisions on cogeneration of electricity from sugarcane.

\section{REFERENCES}

Ahmed AZ, Khaled KM. 2008. Detection of Genetic similarity of Sugarcane Genotypes Retrieved 05 24, 2009, from Gene Conserve 8: 686-697. Available at http://www.geneconserve.pro.br/siteantigo/artigo063.pdf [accessed 24 May 2009].

Ball-Coelho B, Tiessen H, Stewart JWB, Salcedo IH, and Sampaio EVSB. 1993. Residue management effects on sugarcane yield and soil properties in Northeastern Brazil. Agronomy Journal 85:1004-1008

Beater B, Moud R. 1962. The effect of trash on soil temperature in the sugar bealt of Natal. Proceedings of the International Society of Sugar Cane Technologists 11: 378-380.

Chapman LS, Larsen PL, Jackson J. 2001. Trash concervation cane yield in the Mackay district. Proceedings of the Australian Society Sugar Cane Technologist 23: 176- 184.

De Beer AG, Hudson C, Meyer E, Seigmund B. 1996. Green cane harvesting and trash management. Proceedings of the International Society Sugar Cane Technologists (ISSCT): 133 - 141.

Digonzelli PA, Fernández de Ullivarri J, Romero E, Giardina J, Alonso L, Casen S, Tonatto J, Leggio Neme M, Scandaliaris J. 2009. Assessment of two sugarcane management systems: with or 
without post-green-cane-harvest residue retention. In: Proceedings. ISSCT Agronomy Workshop, 8, Uberlandia, Brasil. pp 27-28.

Digonzelli PA, Romero ER, Alonso L, de Ullivarri FJ, Quinteros HR, Fajre S. 2011. Assessing a sustainable sugarcane production system in Tucumán, Argentina. Part 1: Dynamics of sugarcane harvest residue (trash) decomposition. Revista Industrial y Agrícola de Tucumán 88: $1-12$.

Kingston G. 2002. Recognising the in pacot f climate on CCS of sugarcane across tropical and subtropical regions of tlle Australian sugar industry. Proceedings of the Australian Society Sugar Cane Technologist 24: 145-152.

Kingston G, Donzelli JL, Meyer JH, Richard EP, Seeruttun S, Torres J, Van Antwerpen R. 2005. Impact of the green-cane harvest production system on the agronomy of sugarcane. Proceedings of the South African Sugar Technologists' Association 15: 521-533.

Morandini M, Figueroa R, Pérez Zamora F, Scandaliaris J. 2005. The effects of green cane trash blanket on soil temperature, soil moisture and sugarcane growth. In: Proceedings of the ISSCT Congress, 25, Guatemala, Guatemala. pp. 231-236.

Murombo M, Takavarasha E, Wiseman J. (1997). Green cane harvesting at Mltwasine Estate, Zimbabwe. Proceedings of the South African Sugar Technologists' Association 71: 30-32.

Núñez O, Spaans E. 2007. Evaluation of green-cane harvesting and crop management with trashblanket. In: Proceedings of the ISSCT Congress, 26, Durban, Sudáfrica. pp 131-142.

Olivier FC, Singels A. 2006. The effect of plant residue layers on water use and growth of irrigated sugarcane. Proceedings of the South African Sugar Technologists' Association. 80 178-181.

Olivier FC, Lecler NL, Singels A. 2009. Increasing water use efficiency of irrigated sugarcane by means of specific agronomic practices. WRC Report No. 1577/1/09, ISBN 978-1-77005883-5. Water Research Commission, Pretoria, South Africa. pp 127. 
Olivier FC and Singels A. 2012. The effect of crop residue layers on evapotranspiration, growth and yield of irrigated sugarcane. Water $S A, 38: 77-86$.

Olivier FC and Singels A. 2015. Increasing water use efficiency of irrigated sugarcane production in South Africa through better agronomic practices. Field crop research. 176: 87-98.

Orgeron AJ. 2000. Planting rate effects on sugarcane yield trials. MSc thesis, B.S. Louisiana State University, Louisiana.

Ramburan S. 2013. Review and analysis of variety distribution trends in the South African sugar industry: A 2013 perspective. Proceedings of the South African Sugar Technologist Association. 86: 261-272.

Romero ER, Scandaliaris J, Digonzelli P A, Alonso LG, Leggio F, Giardina JA, Casen SD, Tonatto M J, de Ullivarri JF. 2009. Effect of variety and cane yield on sugarcane potential trash. Revista industrial y agrícola de Tucumán 86 (1): 9-13.

Sandhu HS, Gilbert RA, Kingston G, Subiros JF, Morgan K, Rice RW, Baucum L, Shine JM, Jr, and Davis L. 2013. "Effects of sugarcane harvest method on microclimate in Florida and Costa Rica." Agricultural and Forest Meteorology. 177: 101-109.

Thompson GD. 1965. The effects of trash conservation on soil moisture and the sugar cane crop in Natal. Proceedings of the $39^{\text {th }}$ Congress of South African Sugar Technologists' Association. pp 143-156.

Thompson GD. 1966. The production of trash and its effects as a mulch on the soil and on sugarcane nutrition. Proceedings of the South African Sugar Technologists' Association 40: 333-342.

Torres JS, Villegas F. 1995. Green cane management under heavy trash conditions. Proceedings of the International Society of Sugar Cane Technologists. 22: 142-148.

Van Antwerpen R, Meyer JH, Thompson, G.D. 2006. The impact of trashing on yield response in the South African sugar industry: a summary of results from several BT trials. Proceedings of the South African Sugar Technologist Association 80: 130-135. 
Van Antwerpen R, Meyer JH, Turner PET. 2001. The effects of cane trash on yield and nutrition from the long-term field trial at Mount Edgecombe. Proceedings of the South African Sugar Technologists' Association 75:235-241.

Van Antwerpen R, Thorburn PJ, Horan H, Meyer JH, Bezuidenhout CN. 2002. The impact of trashing on soil carbon and nitrogen: ii: Implications for sugarcane production in South Africa. Proceedings of the South African Sugar Technologists' Association 76:269-280.

Viator HP, Wang JJ. 2011. Effects of residue management on yield after three production cycle of a long-term sugarcane field trial in Louisiana. Journal American Society of Sugar Cane Technologists 31: 15-25.

Viator RP, Johnson RM, Boykin DL and Richard Jr. EP. 2009. Sugarcane post-harvest residue management in the temperate climate of Louisiana. Crop Science. 49: 1023-1028.

Wood AW. 1991. Management of crop residues following green cane harvesting of sugarcane in north Queensland. Soil and Tillage Research 20: 69 - 85

Wynne AT, van Antwerpen R. 2004. Factors affecting the economics of trashing. Proceedings of the South African Sugar Technologists' Association 78: 207-214. 